\title{
PENINGKATAN KOMUNIKASI DALAM PELAKSANAAN INTERPROFESSIONAL COLLABORATION PADA PASIEN DI RUMAH SAKIT
}

\author{
Muhaini Atmayana Purba / 181101131 \\ muhainipurba21@gmail.com
}

\begin{abstract}
ABSTRAK
Latar belakang : IPC adalah kemitraan antara tenaga kesehatan dengan latar belakang profesi yang berbeda dan bekerja sama untuk memecahkan masalah kesehatan dan menyediakan pelayanan kesehatan. Namun kenyataannya di beberapa rumah sakit besar di Indonesia masih belum tampak kolaborasi tim. Salah satu faktor yang menghambat pelaksanaan kolaborasi interprofesi adalah karena buruknya komunikasi antar profesi. Tujuan : Tujuan penulisan ini yaitu mengidenifikasi peningkatan komunikasi dalam pelaksanaan interprofessional collaboration pada pasien di rumah sakit. Metode : Metode yang digunakan merupakan literatur review atau suatu perbandingan atau analisis antara satu jurnal dengan jurnal lainnya dari berbagai sumber seperti referensi jurnal, buku teks dan e-book. Hasil : Upaya yang dilakukan untuk meningkatkan komunikasi dalam pelaksanaan interprofessional collaboration adalah dengan menggunakan catatan perkembangan pasien terintegrasi (CPPT). Metode pencatatan terintegrasi ini diharapkan dapat meningkatkan komunikasi efektif antar profesi, pencatatan dilakukan lebih optimal, meminimalkan mis komunikasi, dan meningkatkan keselamatan pasien yang berdampak kepada mutu pelayanan. Kesimpulan : Peningkatan komunikasi dalam praktek interprofessional collaboration dapat ditingkatkan dengan penerapan catatan perkembangan pasien reintegrasi.
\end{abstract}

Kata Kunci : Peningkatan komunikasi, Interprofessional Collaboration (IPC), rumah sakit.

\begin{abstract}
Background : IPC is a partnership between health workers with different professional backgrounds and working together to solve health problems and provide health services. But the reality is that in some large hospitals in Indonesia there is still no team collaboration. One factor that hinders the implementation of interprofessional collaboration is due to poor communication between professions. Purpose : The purpose of this paper is to identify improved communication in the implementation of interprofessional collaboration in patients in hospitals. Method : The method used is a literature review or a comparison or analysis of one journal with other journals from various sources such as journal references, textbooks and e-books. Results : Efforts made to improve communication in the implementation of interprofessional collaboration were to use integrated patient development records (CPPT). This integrated recording method is expected to improve effective communication between professions, recording is carried out more optimally, minimizing mis communication, and increasing patient safety which has an impact on service quality. Conclusion : Improved communication in interprofessional collaboration practices can be improved by applying reintegration patient progress notes.
\end{abstract}

Keywords : Improved communication, Interprofessional Collaboration (IPC), hospitals. 


\section{Latar Belakang}

Menurut UU nomor 44 tahun 2009 pasal 1 ayat 1 tentang rumah sakit, pengertian rumah sakit adalah institusi yang memberikan pelayanan kesehatan paripurna yang menyediakan pelayanan melalui rawat jalan, rawat inap dan gawat darurat. Pelayanan kesehatan yang paripurna menurut UU nomor 44 tahun 2009 pasal 1 ayat 3 adalah pelayanan yang meliputi pelayanan promotif, preventif, kuratif dan rehabilitatif.

Pelayanan kesehatan yang diberikan di rumah sakitdilakukan oleh berbagai profesi tenaga kesehatan. Berbagai profesi yang terlibat dalam pelayanan kesehatan terdiri dari tenaga medis, tenaga psikologi klinis, tenaga keperawatan, tenaga kebidanan, tenaga kefarmasian, tenaga gizi, tenaga keterapian fisik, tenaga keteknisian medis dan teknik biomedika (UU Nomor 36 tahun 2014). Pelayanan kesehatan di rumah sakit merupakan pelayanan dari berbagai profesi kesehatan yang berkolaborasi untuk mengoptimalkan pelayanan kesehatan (Sitorus, 2006).Institute of Medicine (IOM) dan World Health Organization (WHO) meminta tenaga kesehatan profesional untuk bekerja sama dalam
Interprofessional Collaboration (IPC) untuk meningkatkan pelayanan kesehatan (IOM, 2010).

Kolaborasi Interprofesi atau Interprofessional Collaboration (IPC) adalah kemitraan antara orang dengan latar belakang profesi yang berbeda dan bekerja sama untuk memecahkan masalah kesehatan dan menyediakan pelayanan kesehatan (Morgan et al, 2015).

Menurut WHO, IPC terjadi saat berbagai profesi kesehatan bekerja sama dengan pasien, keluarga dan komunitas untuk menyediakan pelayanan komprehensif dan berkualitas tinggi (WHO, 2010). IPC dimaksudkan untuk mencapai tujuan dan memberi manfaat bersama bagi semua yang terlibat (Green and Johnson, 2015).

Tenaga kesehatan harus melakukan praktek kolaborasi dengan baik dan tidak melaksanakan pelayanan kesehatan sendiri-sendiri (Orchar et al, 2005 dan Fatalina, 2015).

Dampak dari kolaborasi yang buruk adalah tingginya kesalahan dalam pembuatan resep di Indonesia (sebanyak 98,69\%) akibat dari kesalahan dalam penulisan resep dokter, apoteker yang tidak tepat dalam penyiapan obat dan pemberian informasi mengenai obat 
tersebut (Easton, 2009). Selain itu menurut National Prescribing Service Australia menyebutkan bahwa 6\% kasus yang terjadi di rumah sakit disebabkan karena efek samping obat dan kesalahan selama perawatan. Hal ini muncul karena buruknya kolaborasi antar profesi kesehatan (Perwitasari, 2010). WHO (2009) menjelaskan bahwa 70$80 \%$ kesalahan yang terjadi di pelayanan kesehatan diakibatkan oleh buruknya komunikasi dan kurangnya pemahaman anggota tim. Kolaborasi tim yang baik dapat mengurangi masalah patient Safety (WHO, 2009).

Kurangnya penerapan kolaborasi interprofesi sesuai dengan penelitian yang dilakukan oleh Fatalina (2015) yang berjudul Persepsi dan Penerimaan Interprofessional Collaborative Practice di Bidang Maternitas pada Tenaga Kesehatan. Penelitian tersebut dilakukan di RSUP Dr. Sardjito. Penelitian tersebut mengatakan bahwa belum terlaksana kolaborasi interprofesi dan masih dilaksanakannya stereotyping kolaborasi tradisional yang beranggapan bahwa dokter adalah leader dan decision making dan pelaksana adalah perawat, bidan dan farmasi.

Selain itu masih kurangnya komunikasi yang terjalin antar anggota profesi. Salah satu faktor yang menghambat pelaksanaan kolaborasi interprofesi adalah karena buruknya komunikasi antar profesi (Setiadi, 2017). Komunikasi adalah aspek terpenting dalam kolaborasi antar profesi. Tanpa komunikasi yang efektif maka perawatan pasien akan menjadi kehilangan arah dan berdasar pada stereotype semata (Cross-Sudworth, 2007).

Komunikasi dalam pelaksanaan IPC juga merupakan unsur penting dalam peningkatan kualitas perawatan dan keselamatan pasien (Reni, A 2010). Menurut The American Nurses Association (ANA, 2010), komunikasi menjadi standar dalam praktek keperawatan profesional. Komunikasi interprofesi menjasi kompetensi inti dalam praktek kolaborasi interprofesi. Untuk melakukan kolaborasi yang baik dibutuhkan komunikasi secara efektif dengan tim kesehatan lain, sehingga dapat melakukan tindakan pelayanan kesehatan yang aman dan efektif. Hal ini juga diatur dalam Permenkes 1691/MENKES/PER/VIII/2011 yang menyebutkan bahwa salah satu dari sasaran keselamatan pasien adalah komunikasi yang efektif. 
Berdasarkan latar belakang tersebut, penulis ingin mengetahui mengenai gambaran upaya yang dilakukan untuk meningkatkan komunikasi dalam kolaborasi interprofesi.

\section{Tujuan}

Tujuan penulisan ini yaitu mengidenifikasi peningkatan komunikasi dalam pelaksanaan interprofessional collaboration pada pasien di rumah sakit.

\section{Metode}

Metode yang digunakan merupakan literatur review atau suatu perbandingan atau analisis antara satu jurnal dengan jurnal lainnya dari berbagai sumber seperti referensi jurnal, buku teks dan e-book.

\section{Hasil \& Pembahasan}

Komisi Akreditasi Rumah Sakit (KARS, 2017) di standar MKE (Manajemen Komunikasi dan Edukasi) 5 mengatur tentang manajemen komunikasi dan edukasi antar profesi kesehatan. Standar MKE 5 menjelaskan bahwa informasi asuhan pasien dan hasil asuhan harus dikomunikasikan antar profesi kesehatan selama bekerja dalam shift. Komunikasi antar profesi kesehatan penting untuk berjalannya proses asuhan. Komunikasi dan informasi antar profesi kesehatan dituangkan dalam catatan perkembangan pasien terintegrasi (CPPT).

Sarana komunikasi antar profesi kesehatan adalah dokumentasi. Pendokumentasian merupakan bukti pelayanan kesehatan yang berupa pencatatan, pelaporan dan penyimpanan kegiatan dalam pengelolaan klien (Klehr, 2009). Salah satu tanda kurangnya komunikasi antar profesi adalah masih digunakannya dokumentasi dalam catatan yang terpisah antar anggota profesi. Catatan yang terpisah kurang menggambarkan respon pasien dalam kegiatan antar profesi kesehatan (Iyer, 2004). Penelitian yang dilakukan oleh Mishra (2015) menunjukkan bahwa sistem pendokumentasian yang tidak terintegrasi menyebabkan ketidak efisienan karena data yang diinput berulang dalam pelaporan di rekam medis. Untuk meningkatkan kualitas komunikasi antar profesi, digunakan catatan profesional kesehatan menjadi satu yang disebut catatan perkembangan pasien terintegrasi. Catatan Perkembangan Pasien Terintegrasi adalah dokumentasi antar profesi pemberi asuhan keperawatan mengenai 
perkembangan pasien dalam bentuk reintegrasi dalam rekam medis pasien (KARS, 2017). Rencana perawatan yang terintegrasi dan tunggal lebih terukur dan lebih baik daripada rencana perawatan yang terpisah. Rencana perawatan pasien harus mencerminkan sasaran perawatan yang khas untuk masing-masing individu sehingga penilaian dan rencana ulang dapat dilakukan (Iyer, 2004).

Paradigma pasien saat ini mulai berubah dengan memusatkan pada perhatian pada pasien (Patient Centered Care). Pelayanan patient centered care ini di terapkan dalam bentuk catatan perkembangan pasien terintegrasi (CPPT) yang dikerjakan oleh para profesional pemberi asuhan keperawatan interprofesi (Komisi Akreditasi Rumah Sakit, 2017). Dengan adanya catatan terintegrasi mewajibkan setiap profesi melakukan pencatatan pada dokumen yang sama. Metode pencatatan terintegrasi ini diharapkan dapat meningkatkan komunikasi efektif antar profesi, pencatatan dilakukan lebih optimal, meminimalkan mis komunikasi, dan meningkatkan keselamatan pasien yang berdampak kepada mutu pelayanan (Frelita, 2011).
Terdapat hubungan antara peningkatan komunikasi kolaborasi interprofesi dengan pelaksanaan catatan perkembangan pasien terintegrasi. Interprofesi kesehatan memiliki spesialisasi pengetahuan yang berbeda. Catatan perkembangan pasien terintegrasi memfasilitasi transfer informasi antar petugas kesehatan sehingga pelayanan yang diberikan kepada pasien lebih komprehensif dan terarah (Morris \& Boussebbas, 2010). Penelitian yang dilakukan oleh Perry \& Robben (2012) menyatakan bahwa dengan adanya catatan perkembangan pasien terintegrasi meningkatkan kolaborasi antar profesi kesehatan. Penelitian lain yang dilakukan Lestari (2017) juga menunjukkan terdapat korelasi kuat antara komunikasi antar profesi kesehatan dengan pelaksanaan catatan perkembangan pasien terintegrasi.

\section{Kesimpulan \& Saran}

Peningkatan komunikasi secara efektif dengan tim kesehatan lain dibutuhkan dalam pelaksanaan Interprofessional Collaboration sehingga petugas kesehatan dapat melakukan tindakan pelayanan kesehatan yang aman dan efektif. Upaya yang dilakukan untuk meningkatkan 
komunikasi antar profesi adalah dengan catatan perkembangan pasien terintegrasi.

Menurut Komite Akreditasi Rumah Sakit, Catatan Perkembangan Pasien Terintegrasi adalah dokumentasi antar profesi pemberi asuhan keperawatan mengenai perkembangan pasien dalam bentuk terintegrasi dalam rekam medis pasien. Rencana perawatan yang terintegrasi dan tunggal lebih terukur dan lebih baik daripada rencana perawatan yang terpisah. Rencana perawatan pasien harus mencerminkan sasaran perawatan yang khas untuk masing-masing individu sehingga penilaian dan rencana ulang dapat dilakukan. Komisi

Akreditasi Rumah Sakit juga mengatur catatan perkembangan pasien terintegrasi dalam standar MKE (Manajemen Komunikasi dan Edukasi) 5.

\section{Daftar Pustaka}

Cahyono, Suharjo. (2008) Membangun

Budaya Keselamatan Pasien dalam Praktik Kedokteran. Yogyakarta : Kanisius

Easton K, Margon T. 2009. Medication

$\begin{array}{ccc}\text { Errors in Outpatients of } A \\ \text { Government } & \text { Hospital in }\end{array}$

Yogyakarta Indonesia. 1(1) : 8 10

Fatalina Femi, Sunartini, Widyandana, Sedyowinarso Mariyono. 2015. Persepsi dan penerimaan Interprofessional Collaborative Practice Bidang Maternitas pada tenaga kesehatan. Universitas Gadjah Mada : Fakultas Kedokteran. Jurnal Kedokteran Indonesia

Iskandar, Heru, Halimi Maksum, dan Nafisah. (2014). Faktor Penyebab Penurunan Pelaporan Insiden Keselamatan Pasien Rumah Sakit. Malang : Fakultas Kedokteran Universitas Brawijaya Malang, 2014 Nugroho, SriH.P., Sujianto,U. Supervisi Kepala Ruang Model Proctor Untuk Meningkatkan Pelaksanaan Keselamatan Pasien. Jurnal Keperawatan Indonesia.20, (1):56-64

Iyer Patricia W, \& Nancy H Camp. 2004. Dokumentasi Keperawatan. Jakarta: EGC.

Klehr, J, dkk. 2009. Menggambarkan dokemuntasi pada catatan sistem elektronik rekam medis yang memberikan catatan elektronik kesehatan. 
Lestari, Yani., Saleh, Ariyanti., Pasinringi, Syahrir. 2017. Hubungan Interprofessional Kolaborasi dengan Pelaksanaan Catatan Perkembangan Pasien Terintegrasi di RSUD Prof Dr H.M Anwar Makkatutu Kabupaten Bantaeng. JST Kesehatan, Januari 2017, Vol. 7 No. $1: 85-90$.

Morgan, S., Pullon, S., McKinlay, E., 2015. Observation of interprofessional collaborative practice in primary care teams: an integrative literature review. Int. J. Nurs. Stud. 52 (7), 12171230.

Morris F \& Boussebbass. 2010. Coordination of Physicians Operational Activities : A Contingency Perspective.

Notoatmodjo, S. (2003). Pendidikan dan Perilaku Kesehatan. Jakarta : PT. Rineka Cipta.

Pohan I. (2015). Jaminan mutu Layanan Kesehatan : Dasar-dasar Pengertian dan Penerapan.Jakarta : EGC

Perry \& Robben. 2012. Impact of Interprofessional Education On Collaboration Attitudes, Skills and Behavior Among Primary
Care Professionals. Journal of Continuing Education In The Health Professions 32 (3) 196 204.

Rahayu, Sri. (2011). Pengembangan Program Patient Safety Berdasarkan Awareness dan Komitmen Individu. RSUD Ibnu Sina Kabupaten Gresik

Rachmawati, Alifa Rizqia, dkk. (2017). ANALISIS PELAKSANAAN TUJUH LANGKAH MENUJU KESELAMATAN PASIEN DI RUMAH SAKIT ISLAM SULTAN AGUNG SEMARANG. JURNAL KESEHATAN MASYARAKAT (e-Journal) Volume 5, Nomor 1 (ISSN: 2356-3346)

R.H, Simamora. (2019). Buku Ajar Pelaksanaan Identifikasi Pasien. Uwais Inspirasi Indonesia

R.H, Simamora. (2019). Documentation Of Patient Identification Into The Electronic System To Improve The Quality Of Nursing Services. International Jurnal Of Sciensific \& Technology

R.H, Simamora. (2019). The Influence Of Training Handover Based SBAR Communication For Improving Patients Safety. Indian 
Journal Of Public Health

Research \& Deveropment.

Undang-Undang Republik Indonesia

Nomor 44 tahun 2009 tentang

Rumah Sakit.

Undang-Undang Republik Indonesia

Nomor 36 tahun 2014 tentang

Tenaga Kesehatan.

Widajat, Rochmanadji. (2009). Being a

Great and Sustainable Hospital.

Jakarta : PT Gramedia Pustaka

Utama

World Health Organisation (WHO), 2010. Framework for Action on Interprofessional Education and Collaborative Practice. World Health Organisation, Geneva. World Health Organisation (WHO), 2009. Human Factors in Patient Safety Review of topics and Tools.World Health Organisation, Geneva. 